\title{
Reflection on the Visit to Turkey
}

\author{
Mehran Banaei
}

A number of years ago my eyes were badly injured during a recreational soccer game. As a result of this injury, I was temporarily blinded for a few weeks. Although this was a traumatic and frightening experience, it was not without its rewards. The whole ordeal was a lesson in blindness. It taught me how I took my vision for granted all along. It taught me empirically what it means to be deprived of one of the most precious senses. Above all, it taught me how easy it is for one to suddenly lose his vision. When I recovered, I begun to cherish my eyes and used my sense of vision with a great deal of pride, care and appreciation.

Last summer I had the opportunity to work as a graduate intern at the UNHCR head office in Ankara, Turkey. My first duties included researching various refugee-related issues. Eventually, I was given the opportunity to interview asylum seekers and screen them according to the UNH$C R^{\prime}$ s refugee determination criteria.

This experience was similar to my eye injury, because, although it was very depressing, it was nonetheless very rewarding. It brought me close enough to witness the plight of those refugees who were in serious financial, psychological and even physical pain. The uniqueness of such an experience is the realization of the same ubiquitous reality that one witnesses night after night on the television screen, but this time perception of this reality is aided with more than one sense. The focus of this perception is on displaced people who are human beings like everyone of us with flesh, feelings and hopes, but are dehumanized by having been turned into file numbers. One of the most unforgetta-

Mehran Banaei is a research assistant at CRS, and recently completed his M.A. in Philosophy and a Diploma in Refugee Studies at York University. ble incidents while I was there took place during an early morning interview. A middle-aged asylum seeker was just admitted to the office for his first interview. Although the man appeared healthy, he was under so much stress that as soon as he started to reveal his grounds for asylum he collapsed with a heart attack. He died in the office, right in front of the legal officer and an interpreter. I was told later that this was "nothing," incidents such as someone burning himself in front of the UNHCR building or somebody throwing his sick child in front of a vehicle to relieve the child of the pain were common incidents there. My daily experiences were particularly depressing for a new employee who had to face the misery of destitutesand then make a yes or no "moral" decision. Indeed, reading Locke, Hume, Hobbes and all other theoretical writings on ethics meant nothing when it came to a real life situation. It was striking to see that the permanent employees were very accustomed to this situation. It frightened me to think that the same thing could have happened to me if I had stayed there a little longer. There, in the legal unit of the UNHCR, legal officers are involved in making decisions on the future of these applicants. They act like quality control inspectors on an assembly linefiltering out unwanted goods. The irony in this process is that the needless determine the fate of the needy in accordance with ethical values which are relative and culturally biased. Being involved in this pedagogical process was indeed my greatest difficulty, especially when the system is known to be deficient from experiences elsewhere.

As one of the consequences of the Gulf war, the majority of the refugees coming to Turkey were Iraqis, who were fleeing the severe economic hardship imposed on the them by Western economic embargos. The distinction between convention refugee and $\mathrm{mi}$ grant worker is clear in the UNHCR Determination Handbook, and of course "the UNHCR does not act as travel agency" in population movements. Thus, those who do not fit the convention definition are doomed to be rejected. None of the asylum seekers get any benefit from the UN, unless they are first recognized as a convention refugee. The result is tantamount to a disappointing brush-off for a great number of those who seek asylum. The standard and ubiquitous cliche: "we regret to inform you that..., thank you for your interest in UNHCR, we hope that you are successful elsewhere in your future objectives" appears in the only correspondence that a refugee receives from the UNHCR. Indirectly, the rejectees are treated as though they are guilty of committing an embarrassing crime like shoplifting or plagiarizing an essay, while their only "misdeed" is trying to provide better living conditions for their family. "You migrant worker, how dare you impersonate a convention refugee." A "crime" that without any hesitation anyone of us would commit being in their position. Often both the needless and the needy are where they are due an accident of birth and fate. The needless, seeming immune from displacement, are indifferent to the needs of the needy. The needless never think that they too may easily become one of the needy, just as we hardly ever consider that we may lose our precious eyesight.

The rejectees often remain in Turkey illegally, hoping to reach their destination through smugglers. The smugglers, who can hardly be trusted, often prey ruthlessly on the vulnerability of these desperate people. They charge as much as U.S. $\$ 8,000$ to provide them with a forged passport and an airline ticket. While in Turkey, if 
they are caught, they are subject to prosecution and deportation by the Turkish authorities.

As a result of this obviously faulty process, many NGOs and refugee rights advocates have campaigned for broadening the $1951 \mathrm{UN}$ definition of a refugee. Although concerned for human rights, I personally never favoured the idea of changing the "outdated" definition of a convention refugee in order to accommodate the larger number of asylum seekers of $90 \mathrm{~s}$. That is because, I believe that we should always seek an optimal solution as opposed to a band-aid approach and false comfort. Therefore, we must handle any problems at the foundational level, to see what has caused the cracks in the structure in the first place. Thus, we ought to remove the sources which have generated the defects, rather than just dealing with symptoms. Furthermore, if we try to revise the 1951 definition of refugee in order to accommodate the current situation of $90 \mathrm{~s}$, then what are we going to do in the next few decades when the 90 s definition is also outdated? Therefore, it seems that changing the definition every once in a while is far from being an optimal solution or a foundational approach. The solution does not lie in allowing more Iraqis to settle in the West. The solution ought to be in eradicating the problem from its root, which is indeed viable if our priorities are just and correctly focused. For example, if the UN economic blockade against Iraq is lifted then many of these refugees whom I met in Turkey would not abandon their homeland, possessions, culture, way of life, family and beg for membership in a foreign and often hostile society. These refugees are the victims of the so-called "New World Order", which evidently breathes disorder. So long as such a causative factor is left untouched, the plight of refugees will continue to exist. Until then, I believe there is a serious and urgent need for helping the downcast non-convention refugees who are wandering around Turkey and elsewhere in the world. $\square$
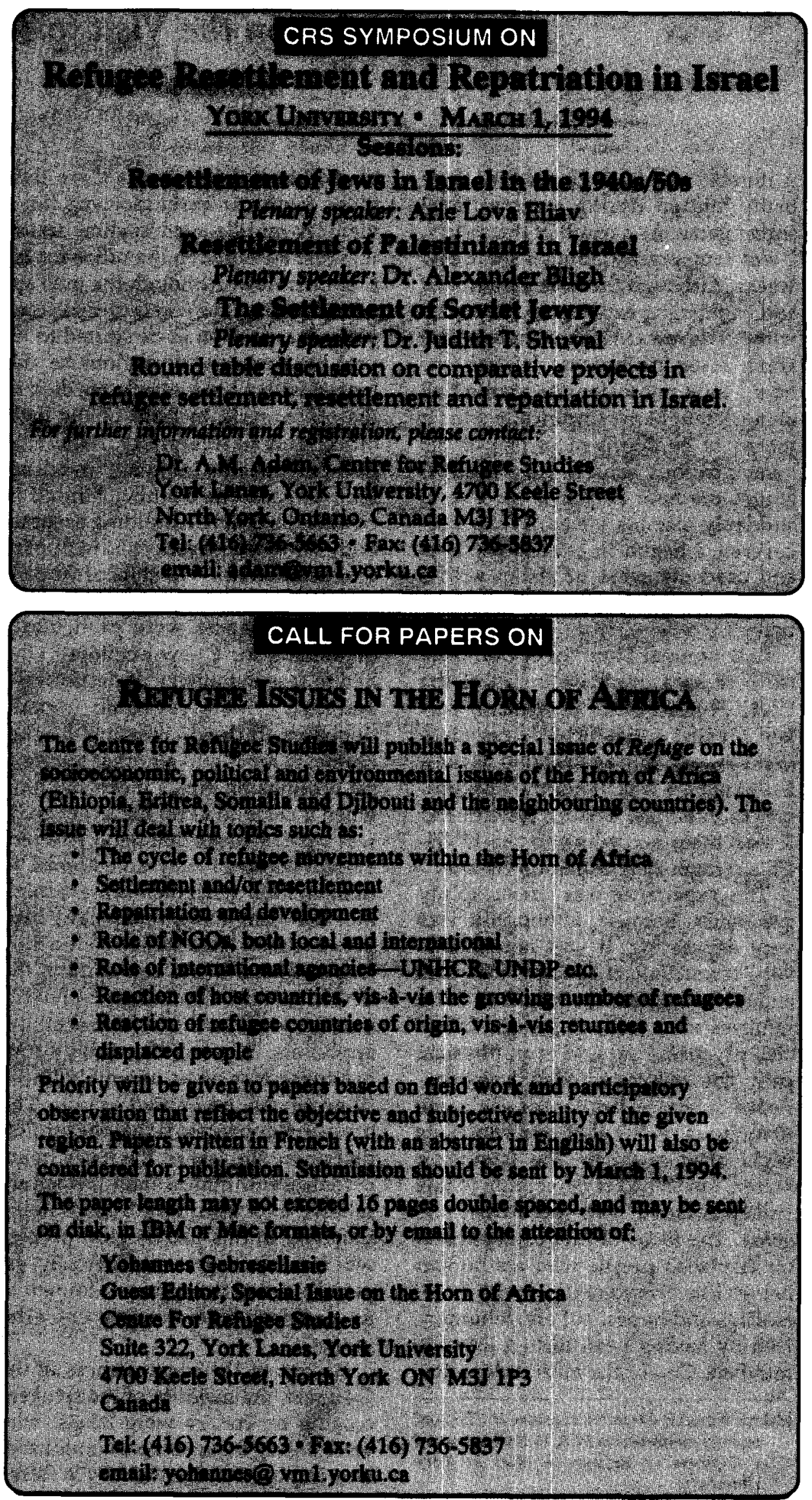


\section{CANTRE FOR RIVUCEE STUDIES \\ ANNUAL DINNER AND MEETING \\ Lichee GaRden ReSTAURANT \\ 595 Bay Street, Concourse Level, Atrium on Bay, Toronto \\ February 17, $1994 \cdot 6: 30$ p.m.}

\section{DONOR INFORMATION}

Corporate Patron A table for ten to the dinner

plus a subscription to Refuge and notification

$\$ 600$

of events sponsored by the Centre

Patron

One ticket for the dinner

$\$ 125$

plus a subscription to Refuge and notification

of events sponsored by the Centre

Friend

One ticket to the dinner

$\$ 60$

Special student rate

$\$ 30$

\section{REGISTRATION FORM}

I would like to reserve table(s). Total number of dinner tickets required:

Enclosed is my cheque in the amount of: $\begin{array}{lllll}\square 600 & \square \$ 125 & \square\end{array} \$ 60 \quad \square \quad \begin{aligned} & \$ 30\end{aligned}$

I will attend the dinner on February 17, 1994.
Menu preference:
a Regular
Vegetarian

I cannot attend, but I am sending a donation to the Centre.

Method of payment: $\square$ Cheque. Please make cheque payable to: Centre for Refugee Studies

Charge to my: $\square$ Visa $\square$ MasterCard $\square$ Amex

Please print information below

Card number

Expiry Date:

Card holder's name:

Signature:

Please send official tax receipts, correspondence, publications and dinner tickets to:

Name

Organization

Address

City

Postal Code

Tel:

Fax:

Please send or fax your completed form to:

Helen Gross, Centre for Refugee Studies

Suite 322, York Lanes, York University

4700 Keele Street, North York, ON M3J 1P3

Fax: (416) 736-5837 - Tel: (416) 736-5663 


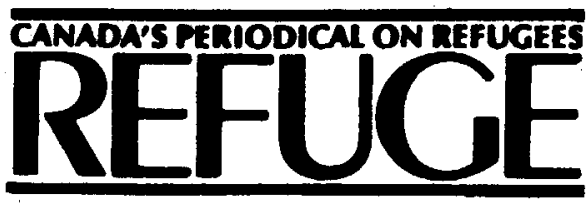

Refuge

York Lanes Pres:

Centre for Refugee Studies

Suite 351, York Lanes, York Univeraity

4700 Keele Street, North York

Ontario, Canada M3J 1P3

Phone: (416) 736-5843 - Fax: (416) 736-5837

Electronic Mail via Bitnet Address:

REFUGEQVM1.YORKU.CA

Postage Paid in Toronto, Canada

Second Class Mail Registration No. 5512

Return Postage Guaranteed

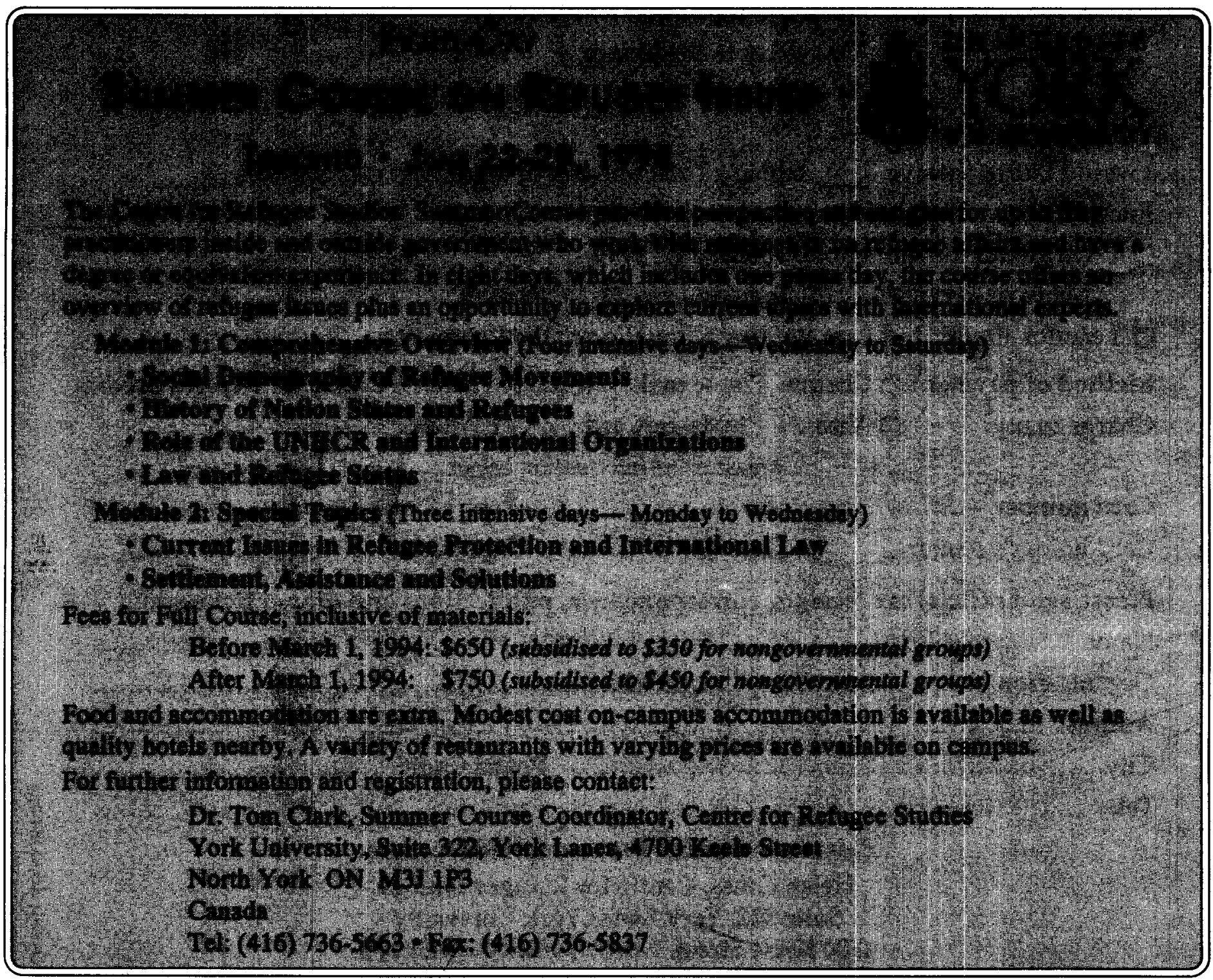

